\title{
Karl Marx Conception of Labor Distribution Equality - Applying to Vietnam in the Trend of Technological Revolution 4.0
}

\author{
PhD - Main lecturer : Hanh, Le Thi \\ University of Finance - Business Administration
}

\begin{abstract}
Summary:
Karl Marx was a brilliant theorist, and a great revolutionary, who became the leader of the international communist and labor movement. He has spent his life and career tirelessly fighting for the cause of communism, for the justice and progress of mankind. The concept of labor distribution equality is one of the great legacies of Karl Marx, which has been and has been the driving force behind the advancement of mankind in the struggle for equality and civilization. In particular, the current 4.0 industrial revolution changes the entire production system of the enterprise, the manufacturing sector, the management system of the nation, as well as the global governance system, High productivity, wealth for society. In the industrial revolution 4.0, workers are required to master and apply technology to serve human life. Therefore, the view of Karl Marx on labor distribution equality - applied to Vietnam in the current trend of industrial revolution 4.0, is very important and urgent.
\end{abstract}

Keywords: Labor distribution, fairness, industrial revolution 4.0

DOI: $10.7176 / \mathrm{DCS} / 9-2-03$

\section{Preamble}

Industrial Revolution 4.0 has unprecedented historical growth, taking place not just on the scale of all areas in a country but also on a global scale. Industrial Revolution 4.0 has the potential to bring many benefits to workers by: (i) increasing labor productivity thereby increasing the level of income; (ii) improve the quality of life through new entertainment and services; and (iii) opening up the labor market by cutting down on travel, transportation costs and the creation of new jobs. In addition to the above mentioned benefits, the Industrial Revolution 4.0 also implies many risks for workers such as: (i) job loss due to mechanical replacement; (ii) no protection of the interests due to a change in the nature of the relationship between the worker and the owner of the means of production by the application of modern technology; and (iii) socially unequal discrimination between highly skilled and low skilled workers, between the owner of the machinery and the worker. Thus, labor distribution equality is based on the notion of Karl Marx There are significant meanings in the 4.0 revolution in Vietnam today.

\section{Content}

\subsection{Theoretical distribution according to the labor of Karl Marx}

In the view of Karl Marx, distribution is a broad issue related to the socio-economic, social ... activities of the state and of the working people, distribution is not limited to the distribution of products. It also involves the distribution of capital goods. Private ownership of the means of production is the cause of labor exploitation, inequality and inequality. The principle of equitable distribution, in Karl Marx, can only be fully enforced when capitalist production is replaced, when private ownership is excluded Karl Marx also points out that the goal of communism is socialization and the human culture of production and distribution, through the transformation of capitalist production relations, the establishment of productive relations Communist. The purpose of the principle of communist distribution is to eliminate exploitation and economic inequalities, enabling all to flourish and enjoy the fruits of development.

Karl Marx, however, found that the process of implementing this principle had to be planned and carried out step by step, gradually and in the long run. In the early stage of transition from capitalism to communism, where production was not sufficiently developed to satisfy the needs of all members of society as well as Capitalist production relations have not been completely abolished immediately, so the value law still regulates labor and governs the distribution of social labor products. So at this stage the principle of distribution is primarily labor or contribution (Follow capacity, labor). Although the principle of labor distribution provides a powerful incentive for the development of individual creative capacity, it is not yet equitable because social inequalities can not be ruled out altogether. Leaning on opportunities and processes among members of society. Inequality will be erased when the productive force develops high in the later stage enough to satisfy the needs of all. The distribution of social income by labor in the socialist period is replaced by the new distribution principle at the communism stage: the principle of distribution according to demand (according to capacity, according to demand). Thus, Karl Marx established the basis of the intrinsic link between labor and income, and labor became an indispensable condition for receiving income. 


\subsection{Labor distribution equality of Karl Marx}

\subsubsection{The rationale for fair and equitable distribution by labor}

With the method of dialectical materialism, on the basis of the selective inheritance of previous advances, Karl Marx pointed out scientific theories, the revolution of social justice is primarily distributed according to labor:

First, social justice is a historical category

Equity is the demand of social life, of human relations with human beings formed in daily activities. Social equality ties in with the interests of the class, the particular social class, and the conditions under which it is born. Thus, social justice changes according to different historical conditions, social justice is an "eternal truth".

Social equality is historical, so there is no universal concept of social justice for all times, nations and classes. In writing, "It is equal to work, and therefore, with the same share of the social fund, in fact, the person is still at risk. more than one person, one person is richer than the other, and so on. To avoid all these shortcomings, the right must be unequal, not equal" 1

Secondly, in socialism, social equality is completely unworkable, but can only be implemented firstly in the principle of labor distribution. When analyzing capitalism. Karl Marx shows the increasingly wealthy capitalist on the suffering and poverty of workers and workers, since private capitalist ownership is the basis of injustice in private society. The distribution, not based on labor, is based primarily on the amount of property and capital, so it represents an unreasonable distribution in capitalism.

According to Karl Marx, in the production of capitalism, social justice is the exchange of parity when buying and selling labor, by the principle of parity dividing the value added after the cycle Produced for workers' wages and capitalist profits, just as much work and money involved in production. But in practice, labor goods are characterized by the fact that when they are put into use, they create a greater amount of value than before they are used, so that the workers only receive " and the value added by their own labor is not paid and turned into profit for the capitalist. This proves that such parity exchange can not be regarded as social equality, manifesting the injustice of the distribution system in capitalism. Ph. Angghen writes ironically: "It is a very special kind of justice" ${ }^{1}$. The worker was at a disadvantage in the fight. The hunger put him in a very disadvantageous situation. But according to the political economy of the capitalist class, that is the culmination of justice" ${ }^{2}$. In line with the critique of the notion of social equity under the principle of "exchange parity" by bourgeois economists. Marx and Angela also criticized both the application of Ricardian theories in an average way. In fact, in the regime of private ownership of capital goods that wish to implement the principle of socialist labor distribution above, it can not become a reality. Both sides must have been placed in the same conditions from the beginning"3

Third, justice in socialism, C. Clear progress, in socialism - the low stage of communist society when capital goods are publicly and equitably linked to principle of distribution according to labor. Labor distribution is, after deducting the amounts needed to maintain production, reproduction, and community life, the rest of the social product will be distributed on the principle of " will get back from the society a number of consumer products worth as much as the amount of labor he provided to society in this form he will get back to society in a form other "4. The main criterion for dignity and social status, the right to enjoy the social welfare of each person, is equivalent to the contribution of that worker to society.

\subsubsection{The view of Karl Marx on labor distribution in socialism}

First, in socialism, the implementation of the principle of labor distribution also accepts certain inequalities among members of society. Because, in socialism, the worker is not fully entitled to the value of his or her labor, but the worker is not the same person as the person who is physically and mentally different from the other, in terms of work capacity and skills, personal talents and family circumstances, they must accept certain inequities. According to Marx, "these deficiencies are unavoidable in the early stages of communist society ... the right can never be at a higher level than the economic regime and cultural development of the society decided by the economic regime ". Real equity distribution is only possible when society is entering a higher stage of development, when people no longer depend on labor allocation; Labor is not merely a means of living but a demand for activity and development. Such a society has gradually acquired in the distant future, "communist society." Social equality is a guiding value and it will be carried out step by step in the process of development towards a society of equality and equality.

The shortcomings of the equitable distribution of labor in socialism have only been overcome completely in communism. "Only then can one go beyond the narrow limits of bourgeois and social law to inscribe on his flag: on the basis of capacity, on demand" ${ }^{5}$ Thus, the equitable distribution according to labor is interpreted by Marx

\footnotetext{
${ }^{1}$ Marks and Ph. The Whole Angels, Volume 19, National Political Publishing House, Hanoi, 1995, p.35

${ }^{1}$ Marks and Ph. Complete Angle, Volume 19, National Political Publishing House, Hanoi, 1995, p.366

${ }^{2}$ Marks and Ph. Complete Angle, Volume 19, National Political Publishing House, Hanoi, 1995, p.367

${ }^{3}$ Marks and Ph. Complete Angle, Volume 19, National Political Publishing House, Hanoi, 1995, p.366

${ }^{4}$ Marks and Ph. Complete Angle, Volume 19, National Political Publishing House, Hanoi, 1995, p.34

${ }^{5}$ Marks and Ph. Complete Angle, Volume 19, National Political Publishing House, Hanoi, 1995, p.36
} 
and Phillips on the basis of historical materialism

Secondly, in order to build a truly just society, the inequity of the ownership relationship must be eliminated. That is, to make everyone equal in relation to the means of production, as a basis for the realization of real justice in society. Equity is not just dependent on the distribution sector, it is governed by the whole nature of the mode of production. "Any distribution of consumer goods only the consequence of the distribution of the right conditions of production; But the distribution of production conditions is a property of the mode of production itself. " The real distribution of labor is only possible when the state system of production is established.

It can be said that the above concepts of Karl Marx are based on the stance of the working class, which is a great step forward in the development of human perception for the purpose of social justice. Only with Karl Marx, social justice fully reflects its values, becoming one of the core goals in the progressive development of humanity.

\subsection{Equitable distribution of labor to Vietnam in the trend of industrial revolution 4.0 2.3.1. Communist Party view on equity distributed by labor}

Technological development has helped Vietnam's economy jump in productivity and productivity. But the path to prosperity of the nation requires governments, businesses and people to see what they have to do, to accept change, to accept abandonment of immediate benefits, to accept the price. From the point of view of Karl Marx is an important argument for the Communist Party of Vietnam to use the policy and policy to implement social justice in the process of building socialism. In the process of formation and development of our Party's awareness of the goal, the road to socialism, the goal of social justice is mentioned very early when our country has not won the government. In the documents of the Party in the pre-reform period, the goal of social justice is embodied in political platforms, economic, cultural and social programs. the Party's conception of social justice in general as well as the equitable distribution of labor according to the socio-economic conditions in each historical period. Particularly, in the documents from 1986 up to now, the Party's view on labor distribution equality has gradually been supplemented and developed. The goal of social justice as well as equity in labor distribution is clearly defined in the general goal of the transition to socialism in our country.

Document of the VI Congress (12/1986), our Party identified the purpose of renovation consists of three components: Renovation for rich people, strong country, civilized society; In the Communiqué of Congress $\mathrm{X}$ (April 2006), our Party has identified social justice as one of the goals in the overall goal of our socialist society: "The rich, Strong country, fair, democratic and civilized society. " The term "social justice" is expressed as a factor in the overall goal, closely related to other factors. At the same time, the Party clearly pointed out: To carry out social progress and equality in each step and each development policy.

The affirmation of equitable distribution by labor and social justice is a development objective that not only symbolizes the superiority of the socialist nature but also fulfills the dream. burning of our people. Before there was peace, independence, and self-reliance to build socialism, our country experienced periods of painful and tragic history, in which social justice remained. desires, ideals. Equity distribution is one of the goals of the socialist society that our people build, in relation to other goals in the overall goal; At the same time, it is relatively independent, meaning the direction of the comprehensive development of the country must ensure fairness. Socialist society in Vietnam must be a just society on the national level in international relations, whose core issue is to ensure national interests in harmony with international interests. Economic development is a central task, but not a development at all costs, but must ensure equity in specific areas, sectors and policies. In particular, fair labor distribution ensures fairness in the fields of politics, culture, society, national defense, security and national defense.

In the Document of the XII Congress (01/2016), our Party continues to affirm and add to the relationship between "economic growth and cultural development, progress and social justice" ${ }^{6}$ as one of Great relationships need to be mastered and handled well. At the same time, affirm the relationship between economic, cultural, human and social, in order to "Ensure the harmony between economic growth with cultural development, human development, progress, social security, social security, environmental protection, sustainable social development"7

\subsection{Labor distribution meets the requirements of the industrial revolution 4.0 in Vietnam today 2.3.1. Impact of industrial revolution 4.0 on Vietnamese workers}

Industrial Revolution 4.0 is based on the highly integrated platform of the digital-physical-biological connection system with the breakthrough of the Internet and artificial intelligence is fundamentally changing. world production. Industrial Revolution 4.0 with features that radically leverage the power of digitization and information technology. This new wave of technology is taking place in every country, impacting strongly on all

\footnotetext{
${ }^{6}$ ommunist Party of Vietnam, Document of National Congress XII, National Political Publishing House - Truth, Hanoi, 2016 , p.80.

${ }^{7}$ ommunist Party of Vietnam, Document of National Congress XII, National Political Publishing House - Truth, Hanoi, 2016 , p.104.
} 
aspects of socio-economic life, leading to a change in the way and force of production in society.

Based on the digital technology platform and integrate all the smart technologies to optimize the production process; Emphasizing the technologies that are and will have the greatest impact is 3D printing technology, biotechnology, new materials technology, automation technology, robots. Industrial revolution 4.0 is the current trend of automation and data exchange in manufacturing technology. It includes physical networking, Internet connectivity and cloud computing. Industry 4.0 facilitates the creation of "smart factories" or "digital factories." In these intelligent plants, virtual space physics systems will monitor the physical processes, creating a virtual copy of the physical world. With IoT, these virtual physics systems interact with each other and with people in real time and through IoS the user will be involved in the value chain through the use of services.

In order to integrate into the civilized world, we must have enough knowledge and skills to adapt to the new age. Deriving from the position, the growing role of technology and the need to prepare employees to work with information (intellectual work, data labor and managerial labor) are increasingly high, creating To promote the independence, creativeness and create conditions for intellectual and intellectual labor to bring into play the strengths and change the sources of the human resource structure to meet revolutionary demands. 4.0.

Firstly, the impact on the quantity and quality of employment through the replacement of labor by machines, robots, artificial intelligence and the application of information technology to a number of branches and trades are ongoing. Quickly penetrate the workplace in the labor market of Vietnam

Revolution 4.0. This will also alter the nature of the job, will do some work disappear but at the same time will create many new jobs. Therefore, Vietnamese laborers are required to meet the requirements of the Revolution 4.0, including those with education, intellectual ability, working capacity, both intellectual and manual labor, than the existing labor force. general; The high quality of labor must be consistent with the scale of human resource development. Trained workers meet the requirements of enterprise and labor market employers. Vietnam's technical labor force has mastered the science and technology, taking on most positions and complicated jobs in the production and business lines which previously hired water experts. out. Demonstration of workers' education is an important criterion that reflects the quality of human resources. At different stages, education requirements for different human resources.

Second, with the digital technology platform, it integrates all information about technology, processes, production methods, industry needs, skills and especially the ability to connect and share across. The world through technology devices will change the way connections between supply and demand in the labor market.

The explosion of information technology makes the information technology penetrate into all areas of social life, deeply change and introduce many new values, new concepts, requiring management system on all fields. The area of social life is forced to change accordingly. The widespread application of scientific and technological achievements in fields, in economic sectors, social organizations, in production and business ... requires workers who are intelligent, hard-working, must be trained to conform with the continuous innovation of science and technology. This requirement requires a high level of technical expertise to be able to adapt well to complex and ever-changing tasks. Therefore, workers must be able to adapt quickly and creatively, producing modern scientific and technological knowledge that meets the requirements of Revolution 4.0.

Third, great impact on the analysis and forecast of labor market information

Revolution 4.0 warns the labor market is experiencing a phase shift in labor supply and supply, where the labor shortage is over. This suggests that the connection between supply and demand in the labor market is still inadequate in Vietnam. . The result is that in many cities even businesses want to recruit staff while unemployed. The uneven distribution of labor in the fields is becoming more pronounced, while we surplus labor not trained in the countryside, in the field of industry, technology lack of labor. Therefore, providing accurate information on the labor market needs as well as the supply of labor will greatly affect the information and forecasting for vocational education institutions from which to concentrate. Training in the labor market that the market is very necessary, exactly meet the requirements of revolutionary 4.0.

Fourthly, to expand international cooperation, international integration and participation in globalization; study, selectively absorb the experience of developed countries to improve the quality of labor to meet the requirements of Revolution 4.0.

The economic globalization of 4.0 revolution involves the international division of labor, the free flow of capital, technology, advanced production and modern management science, that allows All countries - ethnic groups have access to and use experience to better promote their potentials and strengths for economic growth and sustainable development. The demands of globalization and international economic integration always require Vietnamese workers to have new knowledge and skills to acquire new knowledge, and to communicate and integrate quickly and highly. international movement.

\subsubsection{Labor distribution meets the requirements of the industrial revolution 4.0 in Vietnam}

Toward the goal of equitable distribution based on labor in the industrial revolution 4.0, society gradually abolishes exploitation, oppression, injustice and gives true happiness to people, facilitates, opportunities for everyone develops comprehensively. Fair labor distribution meets the requirements of industrial revolution 4.0 


\section{Vietnam needs:}

Firstly, labor distribution is the basic form of distribution, which is the principle of distribution that is most relevant to the economic sector, based on the regime of public ownership of the means of production. Therefore, on the basis of the regime of public ownership of material goods, the regime of exploiters was abolished. Employees who own the material production should inevitably also master distribution by income. Labor is becoming the basis for determining the status and welfare of each person. Therefore, the distribution according to labor is in line with the production relations of all economic sectors existing in our country. Implementing this principle requires laborers with high qualifications and skills. using the expertise and proprietary material production, inevitably also master the distribution of labor distribution. The high level of workmanship is becoming a decisive factor in the application of modern machine tools to production, creating high value products and confirming the employment position of people. Labor in the Industrial Revolution 4.0.

Secondly, the equitable distribution of labor according to the requirements of the industrial revolution 4.0 in Vietnam now needs to eliminate the average distribution, ie that each person will be equally divided equally. Differentiate each person's contribution to social production. Average distribution has caused irrationality and negativity in society. This mode of distribution, in the transitional period in our country has long existed. Up to now, equitable distribution of labor is the basic form, the principle of distribution most appropriate to the economic components based on the regime of public ownership of production materials. In the industrial revolution 4.0, everyone has equal rights to material goods, labor distribution based on the level of labor contributions made by workers, measured labor, is the standard for distribution. Thus, the new realization is fair to society.

Third, the level of production force development is not high, not meet the requirements of revolution 4.0, requires workers ability to adapt quickly and always create, produce scientific and technological knowledge modern. Accordingly, the distribution based on labor is based on the labor contributed to the society, motivating workers to always improve their skills, always work hard, facilitate the allocation and use Labor supply, ensuring balanced and planned social production. Moreover, Vietnamese workers who meet the 4.0 revolution require education about attitudes, attitudes, attitudes and labor discipline, which is one of the reasons that some countries as well as some enterprises They do not accept Vietnamese workers.

Fourthly, in the present period, labor is the means to make a living, the "obligation" and the interests of every citizen, "so every individual has a higher sense of labor, this is a It is very important for Vietnamese workers to participate in the 4.0 revolution. It encourages employees to go further into their professional careers, making the skilled workforce more and more popular, encouraging workers to regularly access and improve their skills, adaptability and creativity in the process. manufacturing. Gradually move to eliminate the difference between mental labor and manual labor.

Thus, fair labor distribution meets the requirements of industrial revolution 4.0 in Vietnam today is indispensable and consistent with the trend, consistent with the level of development of production forces, in accordance with the state-owned production material, in accordance with the production model. The opportunity for Vietnam to approach the revolutionary achievements of science in new production will create a breakthrough, effective participation in the global value chain and accelerate the process of industrialization and modernization of the country.

\section{Conclude}

Karl Marx conception of labor distribution equals important contributions to the Marxist-Leninist theories of value, to the progressive values of the modern age. Labor distribution of Karl Marx is both scientific and revolutionary. Labor-distribution equality meets the requirements of the Industrial Revolution 4.0, which sets out many new issues that need to be further complemented by developments in current practice. When the economy is highly developed, modern machinery, smart factories, cities, robots replace labor, equality of labor distribution is an urgent issue that requires the Party to have specific goals and strategies to bring about fairness to employees in the industrial revolution 4.0 .

\section{References}

1. Vietnam Television Station, Application of Revolution 4.0 in higher education in Vietnam, March 25, 2017.

2. Marks and Ph. Complete Angle, Volume 19, National Political Publishing House, Hanoi, 1995, p. 36, 36, $366,367$.

3. Communist Party of Vietnam, Document of the 12th National Party Congress, National Political Publishing House - Truth, Hanoi, 2016.

4. Ho Chi Minh National Political Academy, Fourth Industrial Revolution: Opportunities and Challenges for Vietnam, Publishing House. Political Theory, Hanoi, 2017,

5. Ngoc Tuyen, Cheap Labor is no longer the advantage of Vietnam in the Industrial Revolution 4.0, http://kinhdoanh.vnexpress.net/truy dated April 14, 2017. 